\title{
The Effects of Interleukin-17 (IL-17)- Related Inflammatory Cytokines and A20 Regulatory Proteins on Astrocytes in Spinal Cord Cultured In Vitro
}

\author{
Shaohui Zonga, Keke Lia Gaofeng Zeng ${ }^{\mathrm{b}} \quad$ Ye Fang ${ }^{\mathrm{a}} \quad$ Jingmin Zhaoc,d \\ aDepartment of Spine Osteopathia, the First Affiliated Hospital of Guangxi Medical University, Nanning, \\ ${ }^{b}$ College of Public Hygiene of Guangxi Medical University, Nanning, 'Department of Osteopathia, the \\ First Affiliated Hospital of Guangxi Medical University, Nanning, dResearch Center for Regenerative \\ Medicine, Guangxi Medical University, Nanning, China
}

\section{Key Words}

Interleukin-17 • Astrocyte • Inflammatory cytokines • Chemokines • A20

\begin{abstract}
Background/Aims: This study focused on investigating the expression of several inflammatory cytokines and chemokines, including regulatory proteins in the astrocytes of mice stimulated with IL-17. Materials and Methods: The cultured astrocytes from the spinal cords of mice were stimulated with IL-17. The expression of interleukin-6 (IL-6), tumor necrosis factor (TNF), monocyte chemotactic protein-1/5 (MCP-1/5) and macrophage inflammatory protein-2 (MIP2) stimulated with IL-17 (50 ng/ml) at different time points ( $3 \mathrm{~h}, 6 \mathrm{~h}, 12 \mathrm{~h}, 24 \mathrm{~h}$ and $48 \mathrm{~h}$ ) were determined using real-time PCR and ELISA. The expressions of A20 (tumor necrosis factor $\alpha$ inducible protein 3, TNFAIP3) and NF-KB were examined using real-time PCR and western blotting. Results: Compared with the control group, the mRNA expression levels of IL-6, TNF, MCP-1/5 and MIP-2 increased significantly at $6 \mathrm{~h}$ after IL-17 stimulation, while the protein expression levels also increased significantly and peaked at $12 \mathrm{~h}$. The mRNA expression level of NF- $\mathrm{KB}$ increased and peaked at $6 \mathrm{~h}$ before gradually declining, while the expression of A20 decreased. The protein expression level of NF-kB increased and peaked at $12 \mathrm{~h}$, while the expression A20 had an opposite response. Conclusion: The study showed that NF-KB may have an effect on the cytokines secreted by astrocytes after IL-17 stimulation. Moreover, both $\mathrm{A} 20$ and NF-KB could regulate the expression and secretion of inflammatory mediators.
\end{abstract}




\section{Cellular Physiology Cell Physiol Biochem 2016;38:1100-1110

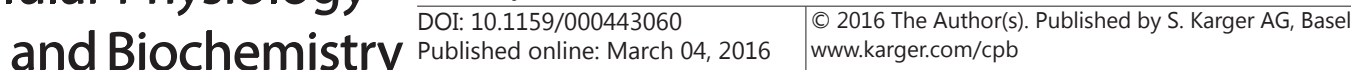 \\ Zong et al.: Effects of IL-17 on Astrocytes In Spinal Cord}

\section{Introduction}

IL-17 (also called IL-17A) is a cytokine subtype that is mainly secreted by CD4 ${ }^{+}$and CD8 ${ }^{+}$ $\mathrm{T}$ cells and NK/T cells, which plays a role in bridging the acquired immune inflammatory response and the natural immune inflammatory response through the induction of inflammatory cytokines (e.g., IL-1 $\beta$, IL-6 and TNF) and chemokines [1]. In the central nervous system (CNS), neurons, astrocytes and microglia are innate immune response cells that can promote the secretion of inflammatory cytokines. Astrocytes are the most widely distributed glial cells in the CNS; they not only have insulation, nutrition, protection and support roles in neurons but also have important roles in the damage and repair process of the CNS $[2,3]$.

IL-17 stimulates astrocytes to release chemokines that cause peripheral neutrophils to infiltrate the disease-afflicted CNS [4]. During the inflammation process in the CNS, the interactions among IL-17, IL-23 and other proinflammatory cytokines produced by astrocytes have negative effects on the treatment and recovery of spinal cord injury (SCI) [5]. Compared with the histology and behavior between IL-17-gene knockout mice models and normal mice after SCI, Hill et al. found that IL-17 had significant roles in the functional recovery and glial scar formation in mice after SCI; in addition, the lack of IL-17 expression could help improve the movement of the mouse and reduce lesion areas, decreasing secondary damage after SCI [6]. As glia cells were not involved in the damage response in this process, there was little effect on the formation of glial scars. The authors also found that a lack of IL-17 could inhibit the expression of inflammatory factors, such as IL-1, TNF, and IL-6, thereby reducing the inflammatory response and leukocytic aggregation and reducing damage to the surrounding normal tissue and improving the function of IL-17-gene knockout mice after SCI [6], which indicated that IL-17 was a key factor during the inflammatory response after SCI.

Chemokines are small molecules that can secret micromolecular proteins and have selective roles in engaging monocytes, neutrophils and macrophages [7]. The chemokine CC subfamily is the best known chemokine family, including MCPs (monocyte chemotactic proteins), while MIP-2 (macrophage inflammatory protein-2) belongs to the chemokine CXC family $[8,9]$. In the process of acute inflammation, MIP-2 is the main chemokine, and longer expressions of MIP-2 lead to more severe inflammation reactions [10]. IL-17 can increase the expression of MCP-1 in endothelial cells, which causes the chemotaxis of peripheral T lymphocytes into the CNS [11]. At present, some proinflammatory factors, including TNF, IL-1 $\beta$ and IFN- $\gamma$, can induce astrocytes to express MCP-1, which might be connected with the activation of NF- $\kappa B$, and Ping et al. demonstrated that TNF can induce mouse monocytes to express MCP-1 through the NF- $\kappa$ B pathway [12].

Astrocytes secreted TNF in the spinal cord and promoted the activation of NF- $\kappa B$ (nuclear factor-kappa B) when combined with TNF receptors, resulting in the production of inflammatory mediators, such as oxygen free radicals, which cause serious damage [1315]. As the induced expression protein of TNF in endothelial cells, A20 (tumor necrosis factor $\alpha$ inducible protein 3, TNFAIP3) was first identified as an anti-apoptotic molecule and was subsequently found to be a negative regulator of NF- $\mathrm{KB}$, a function that is even more important [16]. Deletions of the A20 gene increased the activity of inhibitor NF- $\kappa B$ kinase (IKK), ultimately enhancing the activity of NF- $\mathrm{KB}$ [17]. Therefore, in this study astrocytes of spinal cord in mice were stimulated with IL-17 in vitro to investigate the expression of several inflammatory cytokines and chemokines, including regulatory proteins in the response to early inflammatory injury.

\section{Materials and Methods}

\section{Ethics statement}

This project fully considered and protected the rights and interests of the study objects. It meets the criteria of Ethical Review Committee. The Medical Ethics Committee of First Affiliated Hospital of Guangxi Medical University has approved the protocol (Permission numbers: NO. 2015, KY-E-018). 


\section{Cellular Physiology Cell Physiol Biochem 2016;38:1100-1110 \begin{tabular}{l|l|l} 
and Biochem & DOI: 10.1159/000443060 2016 The Author(s). Published by S. Karger AG, Basel \\
www.karger.com/cpb
\end{tabular} \\ Zong et al.: Effects of IL-17 on Astrocytes In Spinal Cord}

\section{Materials}

Fetal bovine serum (FBS) and DMEM/F12 medium were purchased from Hyclone (Logan, UT, USA). Recombinant Murine IL-17 was purchased from Pepro Tech China (PeproTech, Inc., USA). Trypsin was purchased from Sigma-Aldrich (St. Louis, MO, USA). TNF, IL-6, MCP-1, MCP-5 and MIP-2 ELISA kits were obtained from the Wuhan Cusabio Biotech Company (China). A20 (TNFAIP3) antibody and p-NF- $\kappa B /$ p65 (Ser536) antibody were purchased from Origene (OriGene Technologies, Inc., USA); GAPDH rabbit polyclonal antibody was purchased from Bioss, Inc. (China).

\section{Isolating and culturing mouse astrocytes}

Three-day-old BALB/C mice were used for this experiment. All of the animals were purchased from the Guangxi Medical College Animal Experimentation Center. The suffering of these animals was minimized. The mice were in a $\mathrm{CO}_{2}$ chamber for anesthesia and sacrificed in a quick motion. The isolation of mouse astrocytes in the spinal cord was undertaken using the procedures described by Kerstetter AE [18]. The astrocytes isolated from the spinal cord were placed in an incubator at $37^{\circ} \mathrm{C}\left(5 \% \mathrm{CO}_{2}\right)$. Every three days, the media was replaced and the non-adherent cells were discarded. When it was confluent by $80 \%-90 \%$, oligodentrocytes and microglial cells were discarded using orbital shaker $(200 \mathrm{r} / \mathrm{min})$ at $37^{\circ} \mathrm{C}$ for 6 - $8 \mathrm{~h}$. Then the cells were split at a ratio of 1:2. The third passage of the cells was used in the following experiment. The morphological characteristics of the astrocytes were observed using an inverted microscope. Few irregular shaped cells were observed after 7 days of culturing. After 14 days of culturing, the cells were rich in cytoplasm with many branches and the nuclei were elliptical on one side of the cell body.

The stimulation of astrocytes by $I L-17$

The third passage of the astrocytes cultured in vitro was used for this experiment. These cells were randomly divided into groups stimulated with IL-17. Each subgroup of astrocytes was stimulated with five concentrations of IL-17, ranging from 10 to $200 \mathrm{ng} / \mathrm{ml}(10,20,50,100$, and $200 \mathrm{ng} / \mathrm{ml})$. In addition, the IL17 stimulation time ranged from $3 \mathrm{~h}$ to $48 \mathrm{~h}(3 \mathrm{~h}, 6 \mathrm{~h}, 12 \mathrm{~h}, 24 \mathrm{~h}$, and $48 \mathrm{~h})$.

\section{The detection of inflammatory factors using ELISA}

The expression levels of TNF, IL-6, MCP-1, MCP-5 and MIP-2 secreted into the culture medium after stimulation with IL-17 were determined using ELISA kits according to the manufacturer's instructions. The cells in each subgroup had a density of $1 \times 10^{7}$ per well, which were measured using a cell counting chamber. The medium supernatant from each subgroup was collected and used to evaluate the levels of TNF, IL-6, MCP-1, MCP-5 and MIP-2. First, $100 \mu \mathrm{l}$ of the cell media from each group were placed in a 96 -well microtiter plate at $37^{\circ} \mathrm{C}$. The plates were then covered with a plastic film and incubated at room temperature for $2 \mathrm{~h}$. The liquid was removed from each well without washing, $100 \mu \mathrm{l}$ of biotin antibody was added to each well, and the plates were then incubated for an additional $1 \mathrm{~h}$ at $37^{\circ} \mathrm{C}$. After washing, the unbound antibodies were washed off, followed by the addition of avidin-HRP (1:1000 dilutions). The plates were incubated for $1 \mathrm{~h}$ at $37^{\circ} \mathrm{C}$. Finally, the color reaction was developed by incubation with a TMB substrate and the enzyme reaction was terminated with $50 \mu \mathrm{l}$ of Stop Solution. The OD was read at $450 \mathrm{~nm}$ using an ELISA plate reader (Bio-Rad). All of the samples were assayed in duplicate.

\section{The detection of inflammatory factors using real-time PCR}

Total RNA was extracted from the astrocytes using TRIZOL reagent (Invitrogen, USA) and was used to synthesize cDNA with an RT kit (Ferma, USA). According to the manufacturer's protocol, reversetranscription PCR (RT-PCR) was performed with first-strand cDNA synthesized with $1 \mu \mathrm{g}$ of total RNA and oligo d (T) 18 primers. The primers for the real time-PCR assays for TNF, IL-6, MCP-1, MCP-5 and MIP-2 were designed using Primer Premier 5.0 (Table 1). GAPDH was used to normalize each sample and each gene. All of the samples were assayed in duplicate.

The detection of $A 20$ and $N F-\kappa B$ by real-time PCR

The mRNA levels of A20 and NF- $\kappa B$ were determined using real-time PCR. Each subgroup was stimulated by IL-17 at a concentration of $50 \mathrm{ng} / \mathrm{ml}$ for different times ( $3 \mathrm{~h}, 6 \mathrm{~h}, 12 \mathrm{~h}, 24 \mathrm{~h}$, and $48 \mathrm{~h}$ ). The primers for the real time-PCR assays for A20 and NF- $\kappa$ B were designed using Primer Premier 5.0 (Table 1). 


\section{Cellular Physiology Cell Physiol Biochem 2016;38:1100-1110

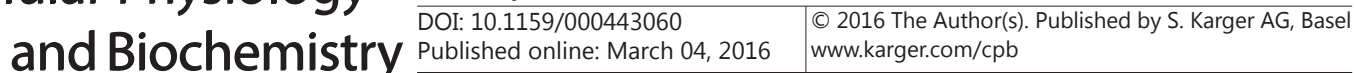 \\ Zong et al.: Effects of IL-17 on Astrocytes In Spinal Cord}

Western blot analysis

After culturing for different times $(3 \mathrm{~h}, 6 \mathrm{~h}, 12$ $\mathrm{h}, 24 \mathrm{~h}$, and $48 \mathrm{~h}$ ), the cells were washed with PBS 3 times and were lysed at $4^{\circ} \mathrm{C}$ with lysis buffer (RIPA lysate containing 1\% PMSF) for $30 \mathrm{~min}$. The total protein from the cells was extracted following the manufacturer's protocols (Beyotime Technology, Inc., Jiangsu, China). Then, the protein concentration in the supernatant was determined using a BCA Protein Assay Reagent Kit (Beyotime Technology, Inc.). An amount equivalent to $40 \mu \mathrm{g}$ of total protein sample were dissolved in $20 \mu \mathrm{l}$ of $1 \times$ sodium dodecyl sulfate loading dye and boiled for 5 minutes. After an equivalent amount of the sample was added, the proteins were separated by 8 and $12 \%$ SDS-PAGE gel electrophoresis and transferred onto nitrocellulose membranes. The membranes were blocked for $2 \mathrm{~h}$ at room temperature with a blocking solution (5\% nonfat milk in Tris buffered saline with Tween 20 (TBST) and incubated overnight at $4^{\circ} \mathrm{C}$ with rabbit polyclonal antibody anti-A20 (1:1000), rabbit polyclonal antibody anti-p-NF- $\mathrm{B}(1: 1000)$ and antibeta actin (1:2500). After washing 3 times for 10
Table 1. Sequences of primers for PCR

\begin{tabular}{cl}
\hline Molecule & \multicolumn{1}{c}{ Sequences(5'-3') } \\
\hline IL-6 & $\begin{array}{l}\text { forward 5'-CCACGGCCTTCCCTAC-3' } \\
\text { reverse 5'-AAGTGCATCATCGTTGT-3' } \\
\text { TNF }\end{array}$ \\
& $\begin{array}{l}\text { reverse 5'-TGGGAGTAGACAAGGTACAACCC-3' } \\
\text { forward 5'-CAGCCAGATGCAGTTAACGC-3' }\end{array}$ \\
MCP-1 & reverse 5'-GCCTACTCATTGGGATCATCTTG-3' \\
MCP-5 $\begin{array}{l}\text { forward 5'-GGAAGCTGAAGAGCTACAGGAGAA-3' } \\
\text { reverse 5'-GAAGGTTCAAGGATGAAGGTTTGA-3' } \\
\text { forward 5'-GCCCCTCCCACCTGCCGGCTGC-3' } \\
\text { MIP-2 } \\
\text { reverse 5'-CTGAACCAGGGGGGCTTCAGGG-3' } \\
\text { forward 5'-TGGGAGCAGTGTTAAAGGCA-3' } \\
\text { A20 } \\
\text { reverse 5'-TCGGAACTGTGGGCAAAACT-3' } \\
\text { forward 5'-GAGGTCTCTGGGGGTACCAT-3' } \\
\text { reverse 5'-AAGGCTGCCTGGATCACTTC-3' } \\
\text { forward 5'-CCTTCATTGACCTCAACTAC-3' } \\
\text { reverse 5'-GGAAGGCCATGCCAGTGAGC-3' }\end{array}$ \\
\hline
\end{tabular}

min with TBST, the membranes were incubated with secondary antibodies (1:2500, Beyotime Technology, Inc.) for $1 \mathrm{~h}$ at room temperature. Then, the membranes were washed with TBST ( 3 times $\times 10 \mathrm{~min}$ ). Finally, the immunoreactive proteins were visualized using an ECL detection kit according to the manufacturer's instructions and were exposed to a radiograph film. The results of the graphs were analyzed by the Digital Gel Imaging Analyst (Nikon 990-Doc 1000, USA). GAPDH was used as a loading control for comparisons between samples.

\section{Statistical analyses}

All data are presented as the means \pm SD. Statistical analyses were performed using SPSS16.0 (SPSS Company, USA). One-way ANOVA followed by the LSD multiple-range test was used to analyze differences between groups. Values of $p<0.05$ (two-tailed) were considered statistically significant.

\section{Results}

The expression of inflammatory factors

The stimulation dose of IL-17 used in the study was determined by ELISA. We used different concentrations of IL-17 $(10,20,50,100$, and $200 \mathrm{ng} / \mathrm{ml})$ to stimulate cells in each subgroup and detected the expression levels of inflammatory cytokines at $12 \mathrm{~h}$. As shown in Fig. 1, the expression levels of IL-6, TNF, MCP-1, MCP-5 and MIP-2 increased with the increasing dosage of IL-17. Compared with the control group, the expression levels of IL-6, TNF, MCP-1, MCP-5 and MIP-2 significantly increased. However, this trend was not significant compared with different concentrations of IL-17 (10, 20, 50, 100, and $200 \mathrm{ng} / \mathrm{ml})$. Thus, the concentration of IL-17 that we used in our next experiment was $50 \mathrm{ng} / \mathrm{ml}$. The expression levels of inflammatory factors were detected at different time points. As shown in Fig. 2, the mRNA expression levels of IL-6, TNF, MCP-1, MCP-5 and MIP-2 increased and peaked at $6 \mathrm{~h}$ $(p<0.05)$. In addition, as shown in Fig. 3, compared with the control, the protein expression levels of IL-6, TNF, MCP-1, MCP-5 and MIP-2 were increased $(p<0.05)$. As time went on, the trend gradually increased and peaked at $12 \mathrm{~h}(p<0.05)$, after which it declined gradually. Moreover, the increasing trends of these inflammatory factors at different time points varied. 


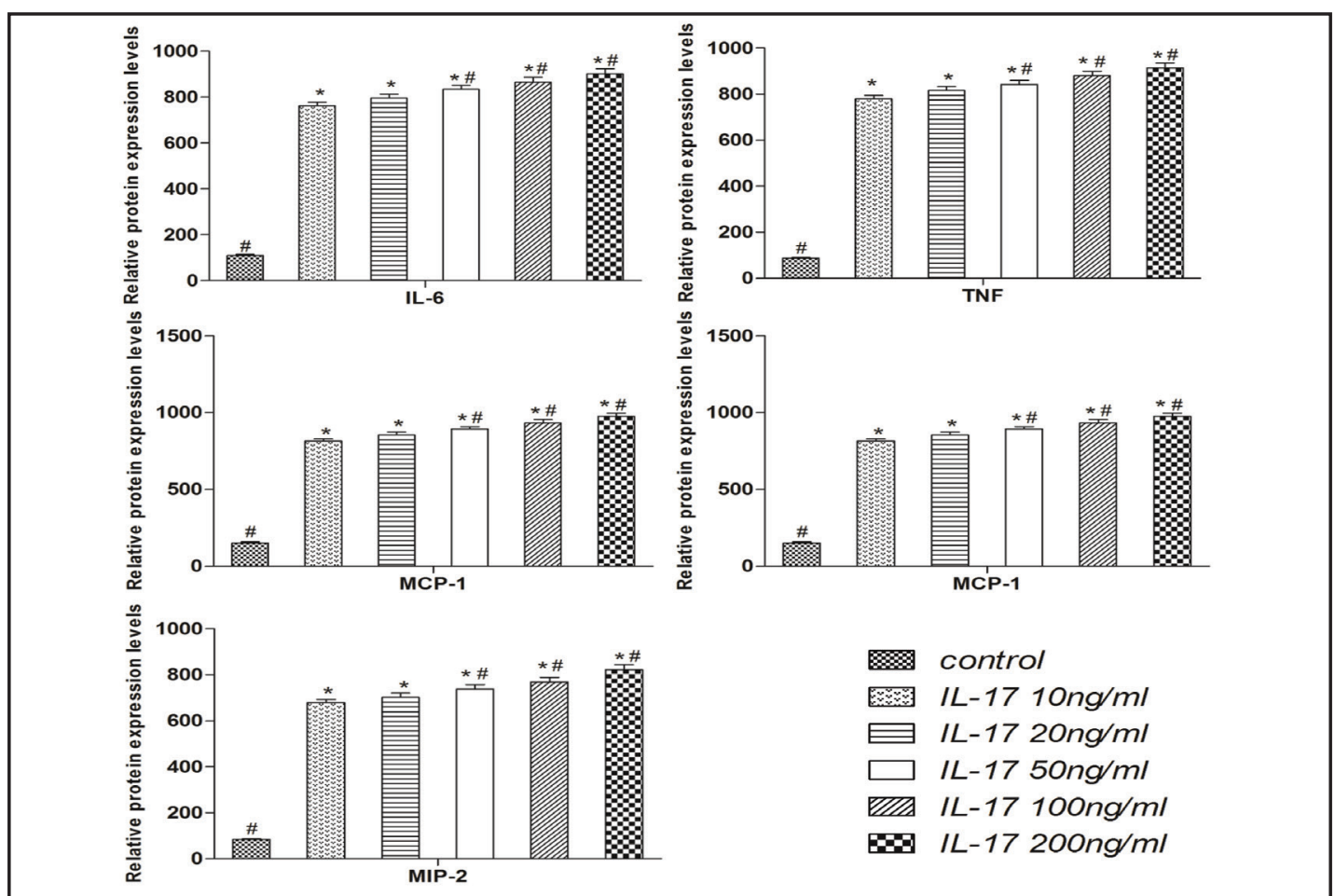

Fig. 1. The determination of IL-17 concentrations. Cells were stimulated with different concentrations of IL-17 (10, 20, 50, 100, and $200 \mathrm{ng} / \mathrm{ml})$. The relative protein levels of IL-6, TNF, MCP-1, MCP-5 and MIP-2 were determined at $12 \mathrm{~h}$. The results are expressed as the means $\pm \mathrm{SD}$. ${ }^{*} \mathrm{p}<0.05$ compared with the control group; \# p<0.05 compared with IL-17 (10 ng/ml) group.

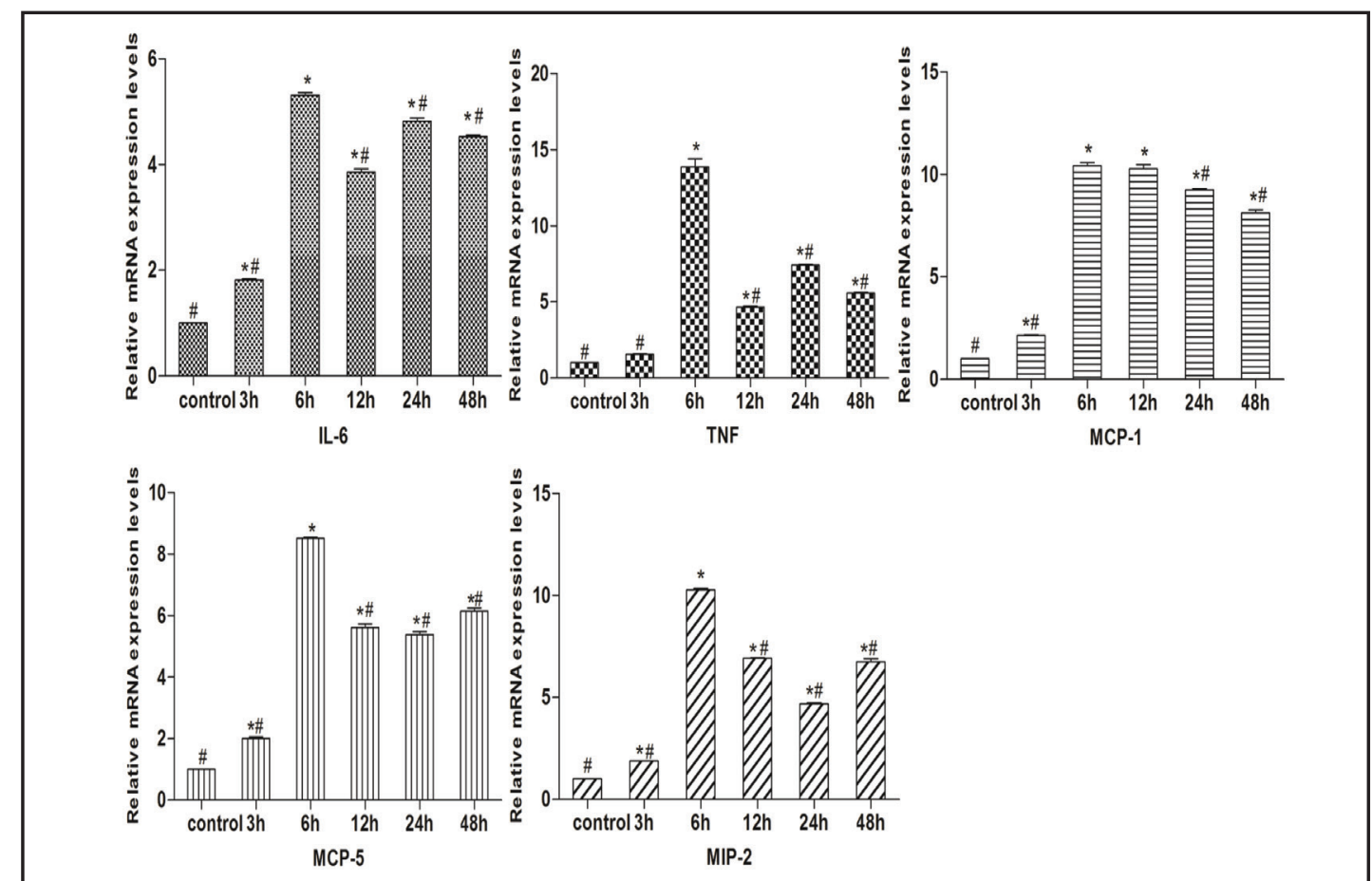

Fig. 2. The relative mRNA expression levels of inflammatory cytokines. Cells were stimulated with IL-17 (50 ng/ml), and the relative mRNA expression levels of IL-6, TNF, MCP-1, MCP-5 and MIP-2 were detected at different time points $(3 \mathrm{~h}, 6 \mathrm{~h}, 12 \mathrm{~h}, 24 \mathrm{~h}$, and $48 \mathrm{~h})$. The results are expressed as the means \pm SD. $* \mathrm{p}<0.05$ compared with the control group; \# p<0.05 compared with IL-17 (stimulated for $6 \mathrm{~h}$ ) group. 


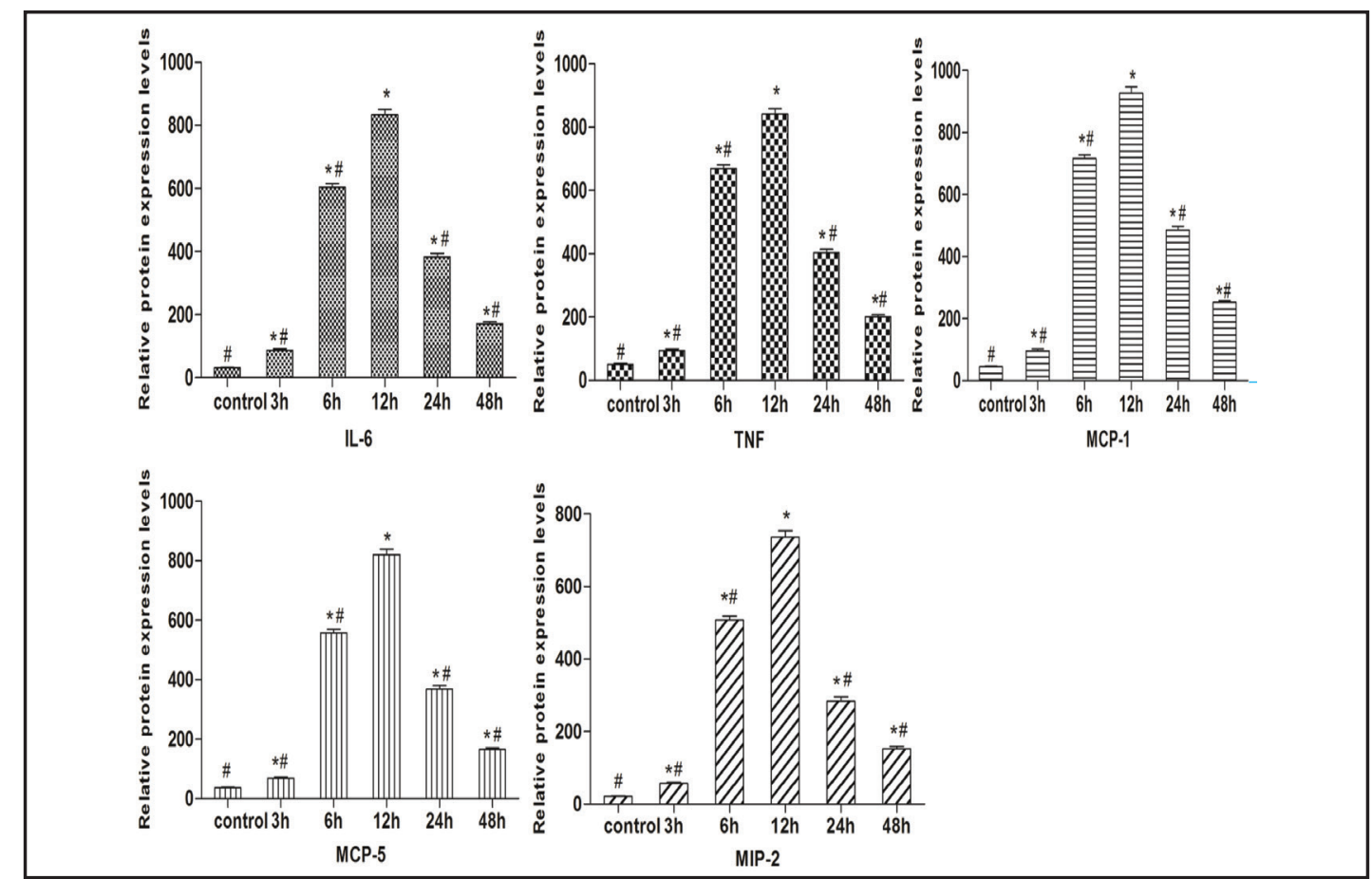

Fig. 3. The relative protein expression levels of inflammatory cytokines. Cells were stimulated with IL-17 $(50 \mathrm{ng} / \mathrm{ml})$, and the relative protein levels of IL-6, TNF, MCP-1, MCP-5 and MIP-2 were detected at different time points $(3 \mathrm{~h}, 6 \mathrm{~h}, 12 \mathrm{~h}, 24 \mathrm{~h}$, and $48 \mathrm{~h})$. The results are expressed as the means \pm SD. $* \mathrm{p}<0.05$ compared with the control group; \# p $<0.05$ compared with IL-17 (stimulated for $12 \mathrm{~h}$ ) group.

Fig. 4. The relative mRNA expression levels of A20 and NF- $\kappa$ B. Cells were stimulated with IL-17 ( $50 \mathrm{ng} / \mathrm{ml}$ ), and the relative mRNA expression levels of A20 and NF- $\kappa$ B were detected at different time points ( $3 \mathrm{~h}, 6 \mathrm{~h}, 12 \mathrm{~h}, 24 \mathrm{~h}$, and $48 \mathrm{~h}$ ). The results are expressed as the means $\pm \mathrm{SD}$. $*$ p $<$ 0.05 compared with the control group; $\# \mathrm{p}<0.05$ compared with IL-17 (stimulated for $6 \mathrm{~h}$ ) group.

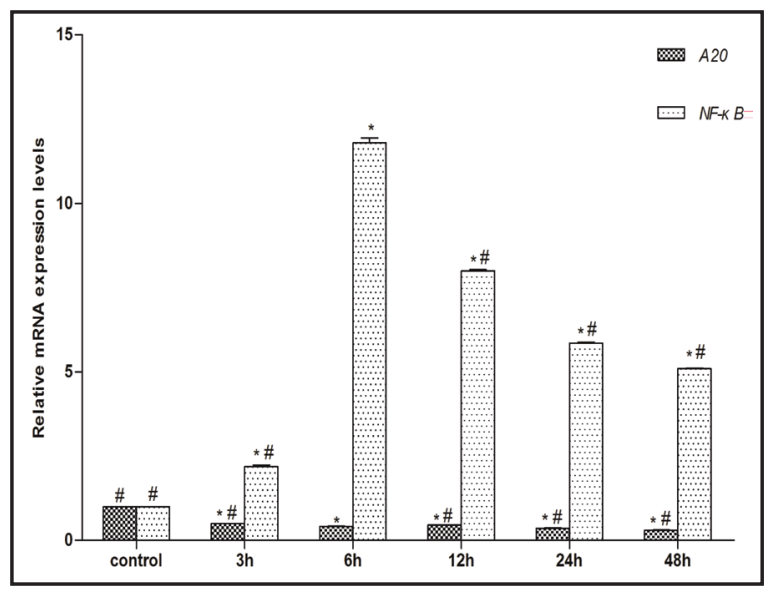

The effect of IL-17-related regulatory proteins $A 20$ and $N F-\kappa B$

In this study, real-time PCR was used to detect the mRNA expression levels of A20

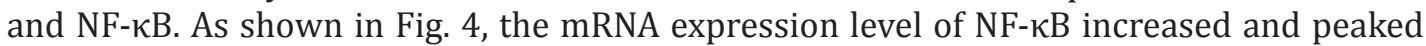
at $6 \mathrm{~h}(p<0.05)$ and then declined gradually. However, the expression of A20 decreased, thus presenting an opposite trend. Western blotting analyses of A20 and p-NF- $\kappa B$ were performed to detect protein expression. As shown in Fig. 5, the protein expression level of NF- $\kappa B$ increased and peaked at $12 \mathrm{~h}(p<0.05)$, while A20 had an opposite trend.

\section{Discussion}

The space between neurons and neurites in the CNS is almost entirely filled with astrocytes, which provide structural support for and separate connections between neurons, 


\section{Cellular Physiology Cell Physiol Biochem 2016;38:1100-1110 \begin{tabular}{l|l} 
and Biochemistry & DOI: 10.1159/000443060 \\
Published online: March 04, 2016 & $\begin{array}{l}\text { C } 2016 \text { The Author(s). Published by S. Karger AG, Basel } \\
\text { www.karger.com/cpb }\end{array}$
\end{tabular} \\ Zong et al.: Effects of IL-17 on Astrocytes In Spinal Cord}

Fig. 5. Western blot analysis of A20 and p-NF- $\mathrm{BB}$. (A) Representative photographs of A20 and p-NF$\kappa \mathrm{B}$ protein levels. (B) A bar graph quantifying the $\mathrm{A} 20$ protein level. (C) A bar graph quantifying the $\mathrm{p}-\mathrm{NF}-\kappa \mathrm{B}$ protein level. The results are expressed as the means \pm SD . $* \mathrm{p}<0.05$ compared with the control group. GAPDH was used as the internal control; \# $\mathrm{p}<0.05$ compared with IL-17 (stimulated for 12 h) group.

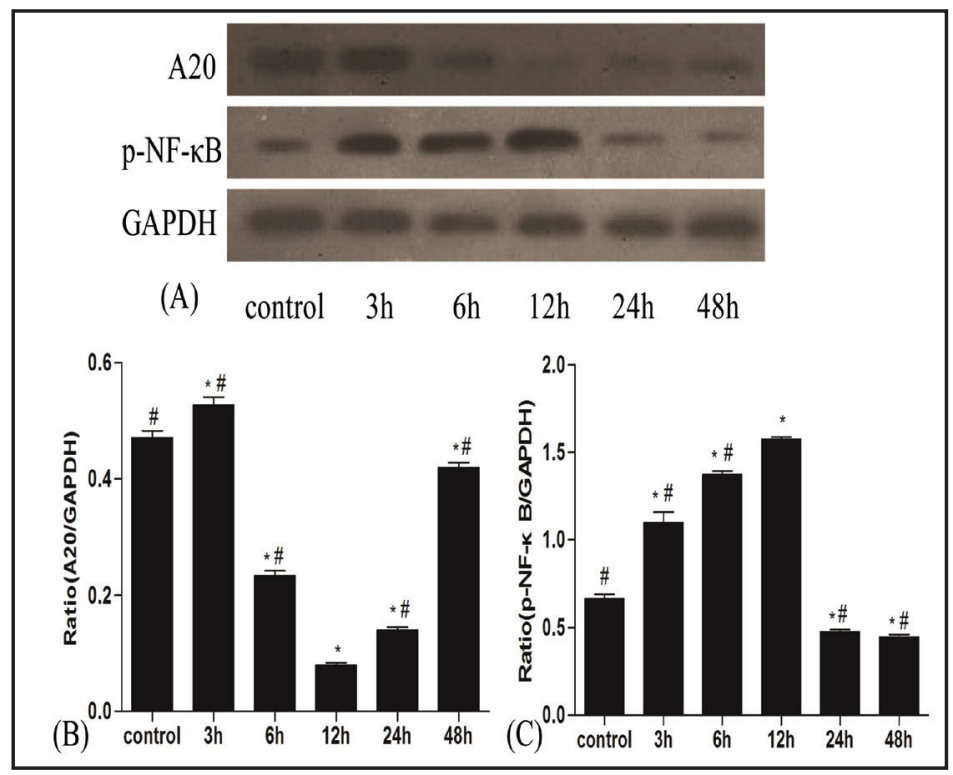

and thus have the protective function of isolation [19]. Moreover, astrocytes could provide nutrients and support neuron metabolism in the spinal cord, maintain the stability of the intracellular environment and the dynamic $\mathrm{pH}$ balance, and produce a series of soluble molecules in the formation of the blood brain barrier (BBB) with endothelial cells [20].

The invasion of inflammatory cells and the release of cytokines and chemokines were caused by a series of cell damage after SCI; these rapid changes affect the internal homeostasis of neurons, oligodendrocytes and astrocytes, and at the same time, the astrocytes were mostly activated as reactive astrocytes [21]. Additionally, these activated astrocytes, referred to as reactive astrocytes, secrete inflammatory factors, such as TNF, IL-6 and others, which in return further promote the activation of inflammatory factors and form a vicious circle [22]. Study found that both CLA (conjugated linoleic acid)-isomers increased TNF and IL-6 mRNA in primary astrocyte cultures indicate that astrocytes may contribute to neuronal inflammation [23]. It also showed that IL-6 could attenuate cell proliferation and anti-apoptotic effects of MDZ in astrocytes [24]. Thus, in this experiment we used IL-17 to stimulate the astrocytes cultured in vitro and to investigate the relationship of several inflammatory cytokines and chemokines, including regulatory proteins, which might provide a theoretical basis for anti-inflammatory therapy of SCI in clinic.

The inflammatory response is the major factor which affects the pathophysiology of SCI. Recently, study has found that IL-17 is a pro-inflammatory cytokine, which plays a key role in the CNS and is related to the innate immune responses as a secondary immune response that affects the secretion of neurotransmitters and the neuron excitability [1], which could influence the functional outcome and the neuroinflammatory response. For example, the expression and secretion of IL-1 $\beta$ and IL- 6 can be induced by IL-17 [25], which are the main cytokines that promote the differentiation of $\mathrm{CD} 4^{+} \mathrm{T}$ cells into Th17 cells. Therefore, the continuously increased expression of IL-17 and its receptor may be a key factor in the progression of the inflammatory response.

Our experimental results showed the mRNA and protein levels of IL-6 and TNF of astrocytes stimulated with IL-17 increased to a peak level in 12 hours, indicating both IL- 6 and TNF played an important role in the early inflammatory response. Therefore, it is the key to effectively control and reduce the intensity and scope of inflammatory reaction after SCI at the early stage.

MCP-1 is a key chemokine in migration regulation and in the infiltration of monocytes and macrophages, while MIP-2 is an important chemokine among neutrophils [26, 27]. Moreover, MCP-1 is mainly expressed by astrocytes, microglial cells and neurons, and it has a chemotactic and activated effect on monocytes. Gene expression and the regulation of MCP-1 


\section{Cellular Physiology Cell Physiol Biochem 2016;38:1100-1110 \\ \begin{tabular}{l|l} 
and Biochemistry Published online: March 04, 2016 & $\begin{array}{l}\text { (c) } 2016 \text { The Author(s). Published by S. Karger AG, Basel } \\
\text { www.karger.com/cpb }\end{array}$
\end{tabular} \\ Zong et al.: Effects of IL-17 on Astrocytes In Spinal Cord}

occur in the distal gene control region and can be combined with NF- $\mathrm{BB}$ and regulated TNF [28]. In this experiment, the increased mRNA and protein levels of MIP-1/5 and MIP-2 of astrocytes stimulated with IL-17 showed a similar tendency, reaching up to a peak level at $6 \mathrm{~h}$ and $12 \mathrm{~h}$ respectively and then gradually decreased, which implied that IL-17 had a close relation with inflammatory cytokines and chemokines.

In the CNS, astrocytes serve as a bridge between the CNS and the immune system [29]. Aberrant expression of cytokines and chemokines in astrocytes often accompanies CNS disorders, such as multiple sclerosis (MS), Alzheimer disease (AD) [29, 30]. MS is an inflammatory/autoimmune and demyelinating disease mediated mainly by $\mathrm{T}$ cells, which causes neurological disorders [31]. The current therapy of MS focuses on a modulation or suppression of immune functions, of which sphingosine-1-phosphate (S1P) receptors on astrocytes involved in demyelination processes and subsequent axonal degeneration are important features [32]. Besides, Tzartos et al. [33] found that in pathological conditions, MS closely related to IL-17 produced by astrocytes in CNS. Our data in this experiment showed that after stimulated with IL-17, expression of cytokines and chemokines (IL-6, TNF, MCP$1 / 5$, and MIP-2) in astrocytes increased rapidly at early stages (mRNAs in 6 h, proteins in $12 \mathrm{~h}$ ). Thus, it demonstrated that in the inflammatory response of CNS, IL-17 both involved in the production and participation of inflammatory diseases (e.g. MS, SCI).

In mammals, the NF- $\kappa \mathrm{B}$ family has five sub-units, two of which are the most important: p50 and p65. Nuclear transcription factor $\kappa \mathrm{B} / \mathrm{p} 65$ (NF- $\mathrm{\kappa B} / \mathrm{p} 65)$, a wide spread cell nuclear transcription factor, can regulate the transcription ability of many genes in tumors and thus regulates tumor cell proliferation and apoptosis [34]. In the central nervous system, activated NF- $\kappa B$ can promote the activation of astrocytes and regulate the expression of proinflammatory cytokines; however, in most cases, the activation of NF- $\mathrm{KB}$ is transient and occurs in cycles. As a result, the regulation of this process is specifically dependent on negative feedback, such as regulation by A20 [35]. Therefore, we know that the main function of A20 is to play a role in negatively regulating NF- $\kappa \mathrm{B}$.

A20 was originally identified as a TNF $\alpha$-induced protein 3 (TNFAIP3), a key regulator of inflammation signaling pathways, as well as a NF- $\kappa B$ inhibitor, which plays a critical role in the regulation of innate and adoptive immunity [36]. Recently, A20 has also been proposed to function as a tumor suppressor. It was found that the inactivation of A20 is associated with the occurrence of B cell tumors, suggesting that it inhibits tumors [37]. Moreover, A20 are essential molecules and terminate the activation of NF- $\kappa B$ [38], which is mediated by the innate receptors of the immune response, including TNF receptor (TNFR), Toll-like receptor (TLR) and nucleotide-binding oligomerization domain protein 2 (NOD2).

Regulatory A20 protein not only regulates the activation of NF- $\mathrm{KB}$ but also is the key suppressor in the signaling pathways of TNFR1, myD88 and NOD2 and regulates some proinflammatory cytokines, including TNF, IL- $\beta$ and IL-6 [39]. Studies have also demonstrated that A20-deficient mice spontaneously develop inflammation reactions in multiple organ systems and die within two weeks [40]. This suggests that A20 has vital anti-inflammatory effects.

In our experiment, we found that the protein level of A20 in the astrocytes decreased at $6 \mathrm{~h}$ after IL-17 stimulation, while the mRNA and protein levels of IL-6, TNF, MIP-2, and MCP1/5 increased significantly. After a period of time, the protein level of A20 gradually increased, while the mRNA and protein levels of the cytokines decreased. Thus, we inferred that there may be a relationship between A20 and these cytokines.

Studies have found that IL-17 could activate signaling pathways, such as JAK (Janus kinase) and PI3K, when combined with IL-17R, and this in turn could result in the activation of NF- $\kappa B$ [41]. In our study, the protein levels of p-NF- $\kappa B$ increased at $3 \mathrm{~h}$ and peaked at 6 $\mathrm{h}$, while the mRNA and protein levels of IL-6, TNF, MIP-2, MCP-1/5 increased significantly. Thus, we believe that NF- $\mathrm{KB}$ may have an effect on these cytokines secreted by astrocytes after IL-17 stimulation.

In this study, we confirmed that IL-17 could up-regulate the expression of NF- $\kappa B$ in astrocytes. In addition, our study has shown that both A20 and NF- $\mathrm{kB}$ not only affect cellular 


\section{Cellular Physiology Cell Physiol Biochem 2016;38:1100-1110 \begin{tabular}{l|l|l}
\hline DOI: 10.1159/000443060 & $\begin{array}{l}\text { C) 2016 The Author(s). Published by S. Karger AG, Basel } \\
\text { www.karger.com/cpb }\end{array}$ \\
\hline Published ondine: March 04, 2016
\end{tabular} \\ Zong et al.: Effects of IL-17 on Astrocytes In Spinal Cord}

proliferation and growth but also regulate the expression and secretion of inflammatory mediators. Ultimately, inflammatory cytokines, such as TNF, IL-6, MCP1/5 and MIP-2, have a dual role in CNS disease: on the one hand, they are excreted by pathologic tissues to attract monocytes/macrophages to the damaged areas to participate in tissue repair, which is an important component of organism defense. On the other hand, the massive amount of inflammatory cytokines produced in the damaged areas could also cause an exaggerated inflammatory response, which in turn aggravates tissue damage. As IL-17 has a close relationship with other cytokines which could mediate multiple inflammatory responses, it is vital to determine how IL-17 effects on the expression levels of other pro-inflammatory cytokines.

More importantly, our study may provide an interesting approach to identifying whether anti-IL-17 therapy could effectively promote the recovery of immune inflammatory response diseases in CNS such as SCI. However, this experiment using cells in vitro is not enough; it still needs further studies using animal models in vivo. As a result, we still need investigations of the molecular structure, biological function, gene mapping and signal transduction mechanism of inflammatory cytokines after immune-activation in the CNS both in vitro and in vivo. The regulatory functions of inflammatory cytokines on other cytokines and inflammatory cells require further investigation to explore how to enhance the beneficial functions while inhibiting the damaging effects in tissues to provide new ideas for the treatment of CNS disease.

\section{Acknowledgements}

In this study, we would like to thank the National Natural Science Foundation of China (81560351) for its support.

\section{Disclosure Statement}

The authors declare that there are no conflicts of interest.

\section{References}

1 Xu S, Cao X: Interleukin-17 and its expanding biological functions. Cell Mol Immunol 2010;7:164-174.

2 Renault-Mihara F, Okada S, Shibata S, Nakamura M, Toyama Y, Okano H: Spinal cord injury: emerging beneficial role of reactive astrocytes' migration. Int J Biochem Cell Biol 2008;40:1649-1653.

3 Sizonenko SV, Camm EJ, Dayer A, Kiss JZ: Glial responses to neonatal hypoxic-ischemic injury in the rat cerebral cortex. Int J Dev Neurosci 2008;26:37-45.

4 Rodgers JM, Zhou L, Miller SD: Act1, scene brain: astrocytes play a lead role. Immunity 2010;32:302-304.

5 Miljkovic D, Momcilovic M, Stojanovic I, Stosic-Grujicic S, Ramic Z, Mostarica-Stojkovic M: Astrocytes stimulate interleukin-17 and interferon-gamma production in vitro. J Neurosci Res 2007;85:3598-3606.

6 Hill F, Kim CF, Gorrie CA, Moalem-Taylor G: Interleukin-17 deficiency improves locomotor recovery and tissue sparing after spinal cord contusion injury in mice. Neurosci Lett 2011;487:363-367.

$7 \quad$ Kobayashi Y: The role of chemokines in neutrophil biology. Front Biosci 2008;13:2400-2407.

8 Ma DD, Fu Y, Yin XH: Research progress in the relationship between chemokines and their receptors and coronary heart disease. Chin Heart J 2015; 27: 221-223.

9 Li SY, Li JS, Wang XY, Liu BJ: Effect of Dusuqing granule on the expression of MIP-2 mRNA at small intestine of rabbit with endotoxin-induced lung injury. Chin J Gerontology 2009; 29: 150-152.

10 Xue ML, Thakur A, Willcox MD, Zhu H, Lloyd AR, Wakefield D: Role and regulation of CXC-chemokines in acute experimental keratitis. Exp Eye Res 2003;76:221-231. 


\section{Cellular Physiology Cell Physiol Biochem 2016;38:1100-1110 \begin{tabular}{l|l|l}
\hline DOI: 10.1159/000443060 & (c) 2016 The Author(s). Published by S. Karger AG, Basel \\
\hline
\end{tabular} and Biochemistry Published online: March 04, 2016 www.karger.com/cpb \\ Zong et al.: Effects of IL-17 on Astrocytes In Spinal Cord}

11 Kebir H, Kreymborg K, Ifergan I, Dodelet-Devillers A, Cayrol R, Bernard M, Giuliani F, Arbour N, Becher B, Prat A: Human TH17 lymphocytes promote blood-brain barrier disruption and central nervous system inflammation. Nat Med 2007;13:1173-1175.

12 Ping D, Boekhoudt GH, Rogers EM, Boss JM: Nuclear factor-kappa B p65 mediates the assembly and activation of the TNF-responsive element of the murine monocyte chemoattractant- 1 gene. J Immunol 1999;162:727-734.

13 Zhou XH, Li LD, Wu LM, Han L, Liu ZD, Yang JX, Lv YW, You CL, Zhou ZH: Increased inflammatory factors activity in model rats with experimental autoimmune prostatitis. Arch Androl 2007;53:49-52.

14 Takeyama K, Mitsuzawa H, Nishitani C, Shimizu T, Sano H, Kunishima Y, Takahashi S, Hotta H, Matsukawa M, Shibata K, Tsukamoto T, Kuroki Y: The 6-fluoro-8-methoxy quinolone gatifloxacin down-regulates interleukin-8 production in prostate cell line PC-3. Antimicrob Agents Chemother 2007;51:162-168.

15 Au RY, Al-Talib TK, Au AY, Phan PV, Frondoza CG: Avocado soybean unsaponifiables (ASU) suppress TNFalpha, IL-1beta, COX-2, iNOS gene expression, and prostaglandin E2 and nitric oxide production in articular chondrocytes and monocyte/macrophages. Osteoarthritis Cartilage 2007;15:1249-1255.

16 Li YQ: [Immune regulation role of A20 and its clinical significance]. Zhongguo Shi Yan Xue Ye Xue Za Zhi 2011;19:851-856.

17 Liu YC, Penninger J, Karin M: Immunity by ubiquitylation: a reversible process of modification. Nat Rev Immunol 2005;5:941-952.

18 Kerstetter AE, Miller RH: Isolation and culture of spinal cord astrocytes. Methods Mol Biol 2012;814:93104.

19 Ciprandi G, De Amici M, Murdaca G, Fenoglio D, Ricciardolo F, Marseglia G, Tosca M: Serum interleukin-17 levels are related to clinical severity in allergic rhinitis. Allergy 2009;64:1375-1378.

20 Sofroniew MV: Reactive astrocytes in neural repair and protection. Neuroscientist 2005;11:400-407.

21 Wang DD: FTY720 induces apoptosis in rat spinal cord astrocytes via JNK and Mitochondria pathway. Nanjing Medical University, Nanjing 2013.

22 Jiang M, Yi CL, Bai XJ: The activation of astrocyte and the repair of spinal cord injury. Int J Orthop 2012;33:48-51.

23 Sartorius T, Drescher A, Panse M, Lastovicka P, Peter A, Weigert C, Kostenis E, Ullrich S, Haring HU: Mice Lacking Free Fatty Acid Receptor 1 (GPR40/FFAR1) are Protected Against Conjugated Linoleic AcidInduced Fatty Liver but Develop Inflammation and Insulin Resistance in the Brain. Cell Physiol Biochem 2015;35:2272-2284.

24 Liu L, You Q, Tu Y, Li Q, Zheng L, Li X, Gu J, Wang G: Midazolam inhibits the apoptosis of astrocytes induced by oxygen glucose deprivation via targeting JAK2-STAT3 signaling pathway. Cell Physiol Biochem 2015;35:126-136.

25 Jovanovic DV, Di Battista JA, Martel-Pelletier J, Jolicoeur FC, He Y, Zhang M, Mineau F, Pelletier JP: IL-17 stimulates the production and expression of proinflammatory cytokines, IL-beta and TNF-alpha, by human macrophages. J Immunol 1998;160:3513-3521.

26 Deshmane SL, Kremlev S, Amini S, Sawaya BE: Monocyte chemoattractant protein-1 (MCP-1): an overview. J Interferon Cytokine Res 2009;29:313-326.

27 Ohtsuka Y, Lee J, Stamm DS, Sanderson IR: MIP-2 secreted by epithelial cells increases neutrophil and lymphocyte recruitment in the mouse intestine. Gut 2001;49:526-533.

28 Xu L, Zhang XJ: Monocyte Chemoattractant Protein-1 and the Central Nervous System Diseases. Int J Cerebrovascular Diseases 2005;13:626-629.

29 Allen NJ, Barres BA: NEUROSCIENCE Glia - more than just brain glue. Nature 2009;457:675-677.

30 Dong Y, Benveniste EN: Immune function of astrocytes. Glia 2001;36:180-190.

31 Hohlfeld R: Multiple sclerosis: human model for EAE? Eur J Immunol 2009;39:2036-2039.

32 Halmer R, Walter S, Fassbender K: Sphingolipids: important players in multiple sclerosis. Cell Physiol Biochem 2014;34:111-118.

33 Tzartos JS, Friese MA, Craner MJ, Palace J, Newcombe J, Esiri MM, Fugger L: Interleukin-17 production in central nervous system-infiltrating T cells and glial cells is associated with active disease in multiple sclerosis. Am J Pathol 2008;172:146-155.

34 Baldwin AS: Control of oncogenesis and cancer therapy resistance by the transcription factor NF-kappaB. J Clin Invest 2001;107:241-246. 


\section{Cellular Physiology Cell Physiol Biochem 2016;38:1100-1110 \begin{tabular}{l|l|l} 
DOI: 10.1159/000443060 & O 2016 The Author(s). Published by S. Karger AG, Basel \\
manw.karger.com/cpb
\end{tabular} \\ Zong et al.: Effects of IL-17 on Astrocytes In Spinal Cord}

35 Werner SL, Kearns JD, Zadorozhnaya V, Lynch C, O'Dea E, Boldin MP, Ma A, Baltimore D, Hoffmann A: Encoding NF-kappaB temporal control in response to TNF: distinct roles for the negative regulators IkappaBalpha and A20. Genes Dev 2008;22:2093-2101.

36 Dixit VM, Green S, Sarma V, Holzman LB, Wolf FW, O'Rourke K, Ward PA, Prochownik EV, Marks RM: Tumor necrosis factor-alpha induction of novel gene products in human endothelial cells including a macrophagespecific chemotaxin. J Biol Chem 1990;265:2973-2978.

37 Honma K, Tsuzuki S, Nakagawa M, Tagawa H, Nakamura S, Morishima Y, Seto M: TNFAIP3/A20 functions as a novel tumor suppressor gene in several subtypes of non-Hodgkin lymphomas. Blood 2009;114:24672475.

38 Sun SC: Deubiquitylation and regulation of the immune response. Nat Rev Immunol 2008;8:501-511.

39 Hymowitz SG, Wertz IE: A20: from ubiquitin editing to tumour suppression. Nat Rev Cancer 2010;10:332341.

40 Lee EG, Boone DL, Chai S, Libby SL, Chien M, Lodolce JP, Ma A: Failure to regulate TNF-induced NF-kappaB and cell death responses in A20-deficient mice. Science 2000;289:2350-2354.

41 Huang F, Kao CY, Wachi S, Thai P, Ryu J, Wu R: Requirement for both JAK-mediated PI3K signaling and ACT1/TRAF6/TAK1-dependent NF-kappaB activation by IL-17A in enhancing cytokine expression in human airway epithelial cells. J Immunol 2007;179:6504-6513. 